\title{
TEM REPLICA OF A FLUORIDE-MISERITE GLASS-CERAMIC GLAZE MICROSTRUCTURE
}

\author{
TEM-REPLIKE MIKROSTRUKTURE STEKLOKERAMIČNE \\ FLUOR-MIZERITNE GLAZURE
}

\author{
Jesus Ma. Rincón, Raquel Casasola \\ Vitreous and Ceramics Lab/Group, Instituto CC Construcción E. Torroja, CSIC, Madrid \\ jrincon@ietcc.csic.es \\ Prejem rokopisa - received: 2014-01-27; sprejem za objavo - accepted for publication: 2014-04-10
}

doi:10.17222/mit.2014.020

\begin{abstract}
Several glazes were obtained for an application onto the surface of clay-based ceramic tiles that are usually produced by fast firing. Original glasses within the $\mathrm{F}-\mathrm{K}_{2} \mathrm{O}-\mathrm{CaO}-\mathrm{SiO}_{2}$ system were obtained and during the sinter- crystallization of glass ceramic, fluoride-miserite $\left(\mathrm{KCa}_{5} \mathrm{Si}_{8} \mathrm{O}_{22} \mathrm{~F}_{2}\right)$ nanocrystals with an amount of $4.5 \% \mathrm{~F}_{2}$ were precipitated in the glassy matrix. These glassy tiles can be used for floor and wall coverings in buildings, for certain decorations in civil engineering and for pavements exhibiting good wear and anti-slip properties. The TEM-replica and extraction-replica methods were revisited for observing the microstructures of these glasses under the conventional TEM to elucidate clearly the phase separation that gives rise to the opalescence of these glasses and is strongly dependent on the fluorine included in the structures of these glasses.

Keywords: TEM-replica method, glass ceramics, glazes, tiles, miserite
\end{abstract}

Pridobljenih je bilo več glazur za uporabo na površini keramičnih ploščic na osnovi gline, ki se navadno proizvajajo s hitrim žganjem. V originalnem steklu iz sistema $\mathrm{F}-\mathrm{K}_{2} \mathrm{O}-\mathrm{CaO}-\mathrm{SiO}_{2}$ so bili s postopkom sintranja in kristalizacije steklokeramike izločeni nanokristali fluor-mizerita $\left(\mathrm{KCa}_{5} \mathrm{Si}_{8} \mathrm{O}_{22} \mathrm{~F}_{2}\right) \mathrm{z}$ vsebnostjo $4,5 \% \mathrm{~F}_{2}$. Te steklaste ploščice se lahko uporabijo na tleh ali stenah poslopij, ali kot dekoracija $\mathrm{v}$ gradbeništvu in za pločnike, ker izkazujejo dobre obrabne in protizdrsne lastnosti. Uporabljena je bila metoda TEM-replik in ekstrakcijskih replik za opazovanje mikrostrukture teh stekel v konvencionalnem TEM za pojasnitev ločevanja faz, ki povzročijo opalescenco teh stekel, kar je močno odvisno od fluora, ki je vključen v strukturi teh stekel.

Ključne besede: metoda TEM-replik, steklokeramike, glazura, ploščice, mizerit

\section{INTRODUCTION}

Glass ceramics developed widely in the previous century and found new applications in the first decade of the 21 st century ${ }^{1}$. These applications include the use of the glass-ceramic processing (nucleation + crystal growth) in the production of improved glazes for ceramic-tile coverings $^{2}$. These new glazes produced from frits give rise to a wide range of crystallites precipitated in the vitreous matrix of a glaze and are compatible with the fast-firing process and, even more importantly, with the traditional clay-ceramic and/or porcelainized substrates. The liquid-liquid phase separation or immiscibility in the glazes susceptible to a transformation in microcrystalline coatings has not yet been well described for ceramic tiles. With respect to the above, the glass ceramics, in which the fluoride phases are crystallized, are of great interest for the production of the materials with high toughness and flexural-strength values.

The aim of this work is to show the microstructures obtained in several original $\mathrm{K}_{2} \mathrm{O}-\mathrm{CaO}-\mathrm{SiO}_{2}$ glasses with different fluorine amounts, close to the composition of the crystalline phase called miserite $\mathrm{K}(\mathrm{Ca}, \mathrm{Ce})_{6} \mathrm{Si}_{8} \mathrm{O}_{22}(\mathrm{OH}, \mathrm{F})_{2}{ }^{3}$ Though TEM/EDS allow us to carry out a microstructure determination of ceramics, due to the difficulties of the ion-thinning preparation, it was the objective of this research to apply the old traditional extraction carbon-triafol replica method to demonstrate the capability of observing the glass-inglass or liquid-liquid phase separation ${ }^{5,6}$, which additionally allowed us to simultaneously perform an analysis of the particle extraction, thus saving the time and cost required for the thinning methods.

\section{MATERIALS AND METHODS}

The original or starting glasses were obtained from some batch compositions with a miserite stoichiometric composition, $\mathrm{K}(\mathrm{Ca}, \mathrm{Ce})_{6} \mathrm{Si}_{8} \mathrm{O}_{22}(\mathrm{OH}, \mathrm{F})_{2}$, without cerium, where the hydroxyl ions were first substituted with fluorine and later, in the second series, corrected with the consecutive additions of mass fractions (5, 8, 9 and 10) \% fluorine added as a pure chemical $\mathrm{CaF}_{2}$ powder. Potassium and calcium were added as carbonates and alumina, as well as silica, as pure oxides. The melting was carried out in a super-kanthal furnace at $1450{ }^{\circ} \mathrm{C}$ for one hour using alumina-silica crucibles from Lomba SL, Galicia, Spain. Table 1 shows the initial, basic compositions and Table 2 shows the corrected and final compositions determined with SEM/EDS for the M-4, M-8 and M-10 glasses. The M-5 composition is the 
closest to the stoichiometric miserite, being similar to $\mathrm{M}-10$ but including $\mathrm{Na}_{2} \mathrm{O}$ to facilitate the melting and the pouring operation after the melting. The M-4 glass includes some alumina stabilizing this glass and a higher amount of $\mathrm{K}_{2} \mathrm{O}$, while M-8 and M-9 allow a comparison of the increased calcium additions. As can be seen in the original composition, the basicity or the $\mathrm{CaO} / \mathrm{SiO}_{2}$ ratio, which is well known, is a factor controlling the viscosity variation at high temperatures in the $0.29-0.58$ range.

Table 1: Initial or theoretical compositions of the "miserite glasses", studied with TEM, in mass fractions, $w / \%$

Tabela 1: Začetna ali teoretična sestava "mizeritnih stekel", preiskovanih s TEM, v masnih deležih, w/\%

\begin{tabular}{|c|c|c|c|c|c|}
\hline Oxide $(w / \%)$ & $\mathrm{M}-4$ & $\mathrm{M}-5$ & $\mathrm{M}-8$ & $\mathrm{M}-9$ & $\mathrm{M}-10$ \\
\hline $\mathrm{Na}_{2} \mathrm{O}$ & - & - & - & - & 5.00 \\
\hline $\mathrm{K}_{2} \mathrm{O}$ & 7.35 & 5.56 & 6.66 & 6.24 & 5.29 \\
\hline $\mathrm{CaO}$ & 26.64 & 33.14 & 20.00 & 25.00 & 31.48 \\
\hline $\mathrm{Al}_{2} \mathrm{O}_{3}$ & 8.00 & - & - & - & - \\
\hline $\mathrm{SiO}_{2}$ & 55.00 & 56.81 & 67.97 & 63.72 & 53.97 \\
\hline $\mathrm{F}\left(\right.$ expressed as $\left.\mathrm{F}_{2}\right)$ & 3.00 & 4.49 & 5.37 & 5.04 & 4.27 \\
\hline Basicity $\left(\mathrm{CaO} / \mathrm{SiO}_{2}\right)$ & 0.48 & 0.58 & 0.29 & 0.39 & 0.58 \\
\hline
\end{tabular}

After the melting of these original glasses, it was necessary to prepare new glasses with the increasing and sequential fluorine additions in order to determine the corrosion of the crucibles and the volatilization of fluorine in this type of glasses. Figure 1 shows that fluorine volatilization growths linearly when the fluorine amount in the miserite glasses is increased. In the same way Figure 2 shows the alumina amounts in the final glasses prepared with the increasing fluorine amount. It can be seen that the alumina amount added to these glasses on the basis of the corrosion of the alumina-silica crucibles also grows linearly, with the silica being in the same range for all the glasses considered, as can be seen in

\section{fluor volatilization (absolute curve)}
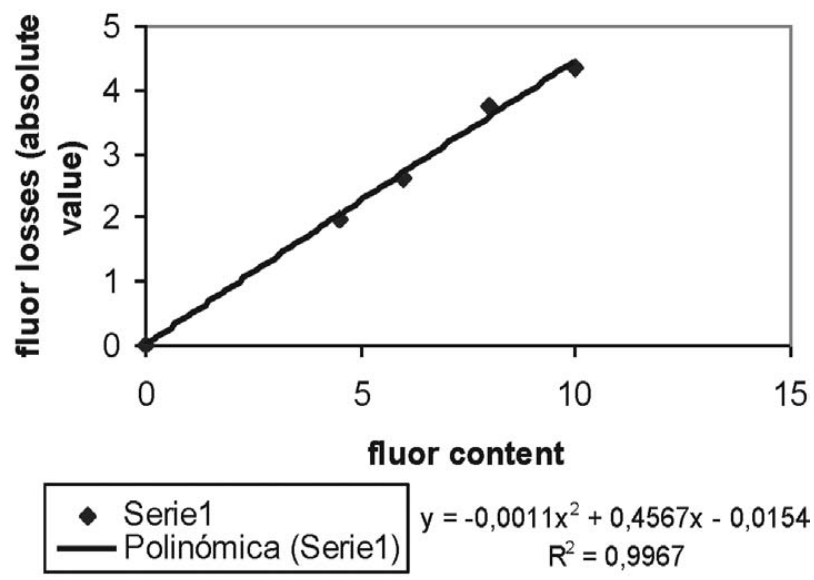

Figure 1: Absolute values of fluorine losses depending on the fluorine added to the original glasses

Slika 1: Absolutna vrednost izgub fluora $\mathrm{v}$ odvisnosti od dodanega fluora originalnim steklom
Table 2, affecting the actual compositions of the glasses analysed with SEM/EDS.

Table 2: Compositions, obtained with SEM/EDS, of the glass samples corrected with the increasing fluorine amount (fluorine and alumina are deduced from the crucible corrosion and the volatilization curves for M-5 and M-9 glasses)

Tabela 2: SEM/EDS-sestava v popravljenih vzorcih stekla s povečano vsebnostjo fluora (fluor in glinica izvirata iz korozije lonca in krivulje izhlapevanja za stekla M-5 in M-9)

\begin{tabular}{|c|c|c|c|c|c|}
\hline Oxide $(w / \%)$ & $\mathrm{M}-\mathrm{E}$ & $\mathrm{M}-5$ & $\mathrm{M}-8$ & $\mathrm{M}-9$ & $\mathrm{M}-10$ \\
\hline $\mathrm{K}_{2} \mathrm{O}$ & 4.79 & 4.61 & 4.56 & 4.52 & 4.48 \\
\hline $\mathrm{CaO}$ & 34.02 & 33.85 & 31.37 & 31.73 & 32.21 \\
\hline $\mathrm{Al}_{2} \mathrm{O}_{3}$ & 4.63 & 4.98 & 7.66 & 7.70 & 7.87 \\
\hline $\mathrm{SiO}_{2}$ & 54.05 & 53.58 & 52.13 & 51.37 & 50.82 \\
\hline $\mathrm{F}\left(\right.$ expressed as $\left.\mathrm{F}_{2}\right)$ & 2.51 & 2.80 & 4.27 & 4.90 & 5.63 \\
\hline Basicity $\left(\mathrm{CaO} / \mathrm{SiO}_{2}\right)$ & 0.62 & 0.63 & 0.60 & 0.60 & 0.63 \\
\hline
\end{tabular}

Then, the final compositions of the sequential fluoride-miserite glasses show that the potassium amount is stable in different compositions, being volatile to the same extent in all the glasses studied. Calcium is also stable in all the glasses and close to the stoichiometric miserite composition. Even the basicities of these glasses are very similar, with the increasing fluorine amount being in a very narrow range of $0.60-0.63$. However, the alumina based on the crucible corrosion grows with the increasing fluorine amount.

In order to investigate the microstructures of the original or starting glasses formulated around the miserite composition, the TEM-replica method was used to avoid the expensive and time-consuming preparations of the ion-thinning methods. Thus, the double triafolcarbon replica method used for years for observing very

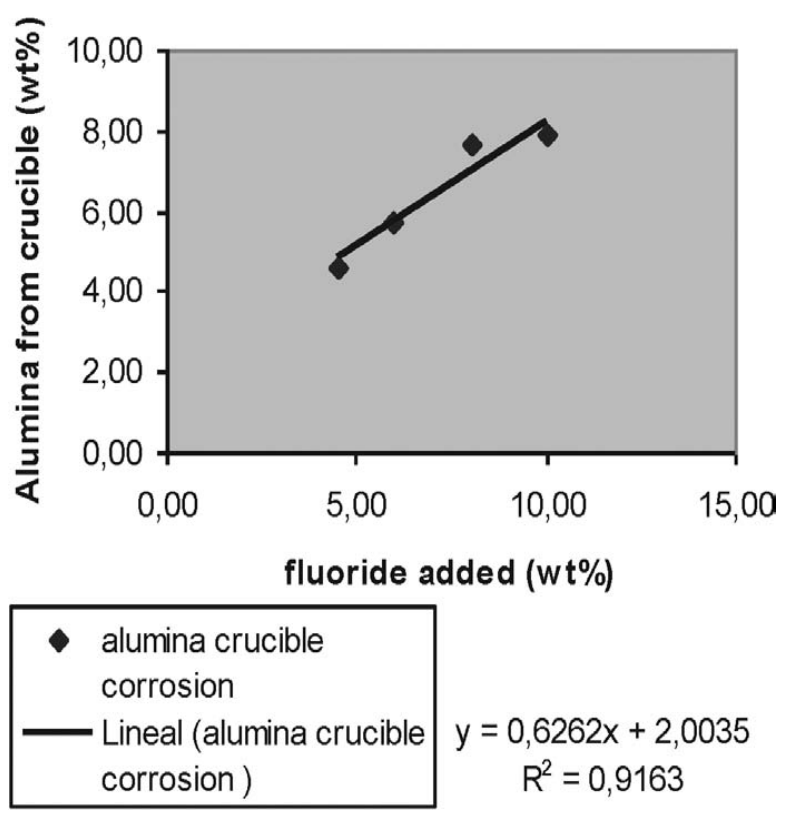

Figure 2: Alumina amounts determined with SEM/EDS versus the fluoride added to the sequential original glasses

Slika 2: Vsebnost glinice, ugotovljene s SEM/EDS, v odvisnosti od dodajanja fluorida zaporednim steklom 


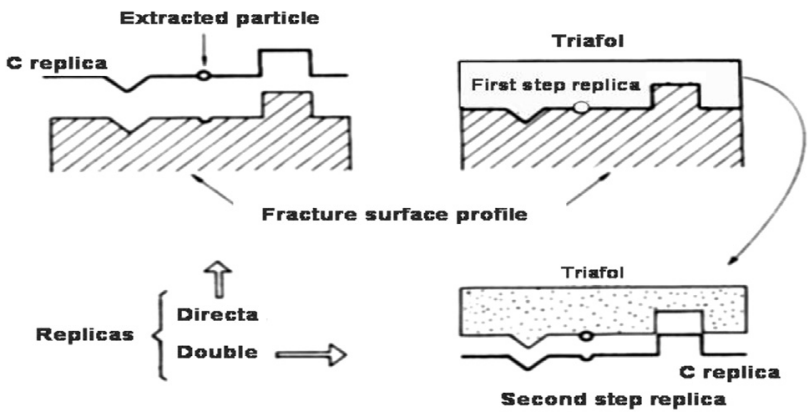

Figure 3: Succesive steps for the preparation of direct and double triafol-carbon replicas 7

Slika 3: Zaporedje stopenj priprave neposrednih in dvojnih replik triafol - ogljik ${ }^{7}$

fragile samples with TEM was revisited as shown by Rincón et al. ${ }^{7}$ Figure 3 shows a simple drawing of the method steps from a fresh fracture and HF $2 \%, 10 \mathrm{~s}$, to the etched glass surfaces. The final carbon-replica skins were deposited on $3 \mathrm{~mm} \mathrm{Cu}$ grids after transfering, smooth drying in an acetone bath and dissolving the first triafol plastic replica. The TEM equiment for the final observation of the replicas was a Philips CM-10 instrument working at $100 \mathrm{kV}$.

\section{RESULTS AND DISCUSSION}

Figures 4 and $\mathbf{5}$ show a summary of the main observations of the microstructures of the fluoride-miserite composition glasses. In the M-4 glass (Figure 4) a clear liquid-liquid phase separation of dispersed droplets with some networks in some areas can be seen.

In the case of glass M-5, the glass-in-glass phase separation is not present due to the crystallization of very small crystallites with an elongated shape in some cases. According to the binary $\mathrm{CaO}-\mathrm{SiO}_{2}$ phase diagram these
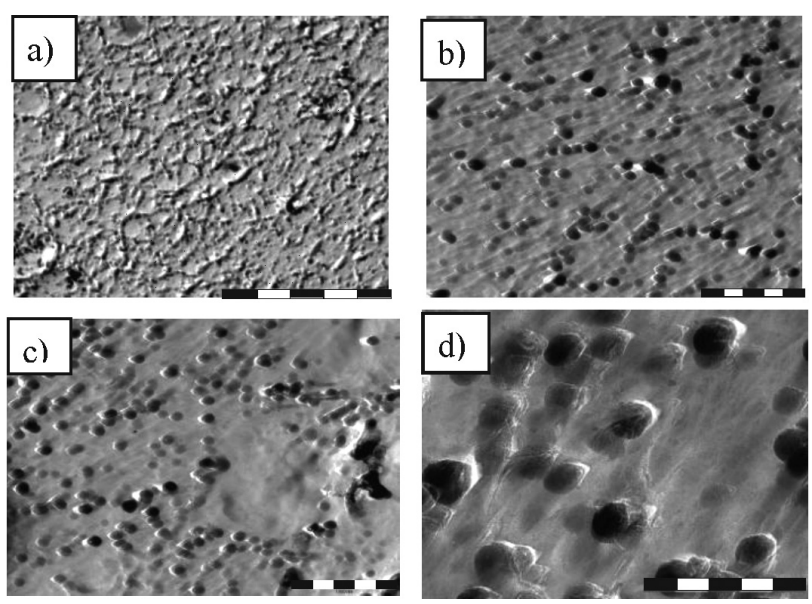

Figure 4: TEM micrographs of double replicas of M-4 glass: the inserted bars correspond to these magnifications: a) $5000 \mathrm{~nm}$, b) 1000 $\mathrm{nm}, \mathrm{c}) 1000 \mathrm{~nm}$ and d) $500 \mathrm{~nm}$

Slika 4: TEM-posnetki dvojnih replik iz stekla M-4: prikazano merilo ustreza naslednjim povečavam: a) $5000 \mathrm{~nm}$, b) $1000 \mathrm{~nm}$, c) $1000 \mathrm{~nm}$ in d) $500 \mathrm{~nm}$

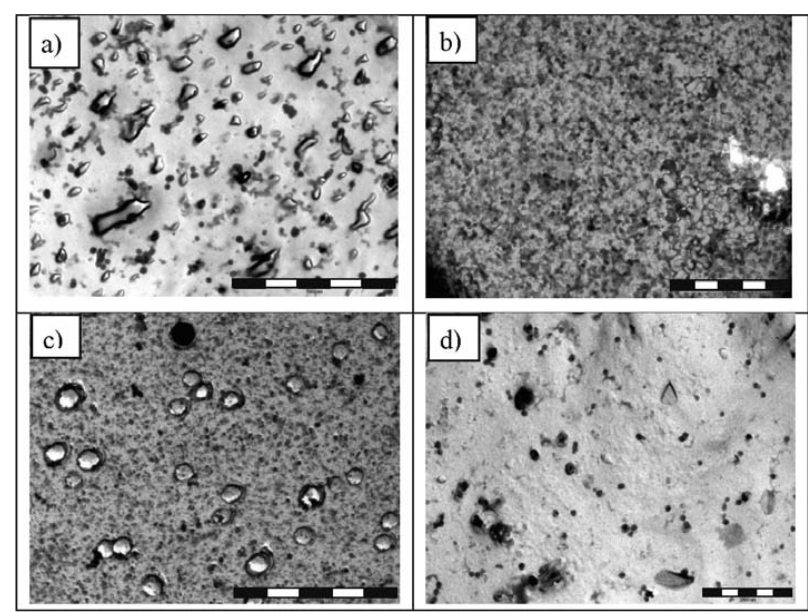

Figure 5: TEM double-replica micrographs for: a) M-5, b) M-8, c) M-9 and d) M-10 glasses: the inserted bars correspond to these magnifications: a) $5000 \mathrm{~nm}$, b) $2000 \mathrm{~nm}$, c) $5000 \mathrm{~nm}$ and d) $2000 \mathrm{~nm}$ Slika 5: Mikroposnetki TEM dvojne replike iz stekel: a) M-5, b) M-8, c) M-9 in d) M-10; vrisano merilo pomeni ustrezno povečavo: a) 5000 $\mathrm{nm}$, b) $2000 \mathrm{~nm}$, c) $5000 \mathrm{~nm}$ in d) $2000 \mathrm{~nm}$

Table 3: Quantitative evaluation of the glass-in-glass phase separation and the crystallites precipitated in the miserite glasses from the TEM replica observations

Tabela 3: Kvantitativna ocena izločanja stekla v steklu in izločkov kristalitov v mizeritnih steklih iz opazovanj TEM-replik

\begin{tabular}{|c|c|c|c|}
\hline $\begin{array}{c}\text { Original } \\
\text { glasses }\end{array}$ & $\begin{array}{c}V_{\mathrm{f}}(\text { esti- } \\
\text { mated) } / \%\end{array}$ & $\begin{array}{c}\text { Droplet average } \\
\text { diameter } \\
(\mathrm{nm} \pm 10 \mathrm{~nm})\end{array}$ & $\begin{array}{c}\text { Crystal average } \\
\text { diameter } \\
(\mathrm{nm} \pm 20 \mathrm{~nm})\end{array}$ \\
\hline M-4 & 50 & 120 & No crystallites \\
\hline M-5 & 30 & No droplets & $800-1000$ \\
\hline M-8 & 80 & $\begin{array}{c}130 \\
\text { (interconnected) }\end{array}$ & clusters $=1800$ \\
\hline M-9 & 80 & 100 & 830 \\
\hline M-10 & 10 & $\begin{array}{c}100 \text { (very few } \\
\text { droplets) }\end{array}$ & 480 \\
\hline
\end{tabular}

crystals in the M-5 glass must be of wollastonite, coexisting with the liquid phase.

For the other glasses investigated with TEM, the representative micrographs obtained with the replica observations are shown in Figures 5a to 5d. It can be seen that the M-8, M-9 and M-10 glasses show different microstructures. Thus, in the M-8 glass, there are clusters of crystals coexisting with opaque nanocrystals, possibly of cuspidine and/or miserite. The microstructure of glasses M-9 and M-10 is completely different, there are rounded and pseudo-polyonal habit crystallites that must be undissolved $\mathrm{Ca}_{2} \mathrm{~F}$ in the glassy matrix. Droplets are shown at higher magnifications. In these glasses the $\mathrm{Ca}_{2} \mathrm{~F}$ crystals coexist with very small nanodroplets of the residual phase separation or, more probably, the nanocrystals of miserite (dark nanocrystals) and cuspidine (white nanocrystals). Table 3 shows volume fraction of immiscibility and size of droplets and nanocrystals.

When the compositions of these miserite glasses are located in the binary $\mathrm{CaSiO}_{3}-\mathrm{SiO}_{2}$ diagram taken from ${ }^{8}$ (Figure 6), showing the over-liquidus glass-in-glass 


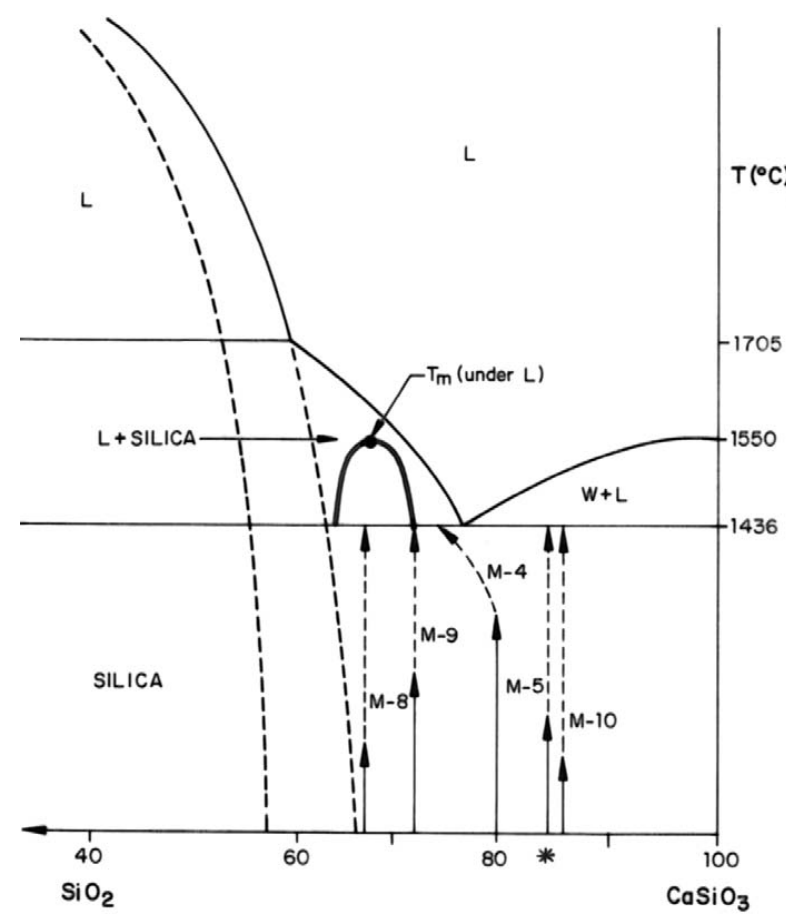

Figure 6: $\mathrm{CaSiO}_{3}-\mathrm{SiO}_{2}$ binary system with the liquid-liquid phaseseparation zone (a phase-separation dome below the liquidus and near the eutectic and/or an extension to the third component are proposed) (modification of the figure from $^{8}$ )

Slika 6: Binarni sistem $\mathrm{CaSiO}_{3}-\mathrm{SiO}_{2} \mathrm{z}$ ločenim področjem izločanja talina-talina (predlagano je izločanje kupolaste faze pod likvidusom blizu evtektika in/ali razširitev do tretje komponente; prirejeno po viru $^{8}$ )

phase separation, it can be seen that all the considered compositions are far from this zone and that droplets of the phase separation are present in the M-4, M-8 and M-9 glasses. The M-8 and M-9 compositions are located in the two phases of silica + liquid area below the liquidus. The M-4 composition is very close to the eutectic, between the above-mentioned area and the wollastonite + liquid area below the liquidus. The M-5 and M-10 glasses with very similar compositions are located in the wollastonite + liquid area. Therefore, these glasses were produced during the cooling as a precipitation of very
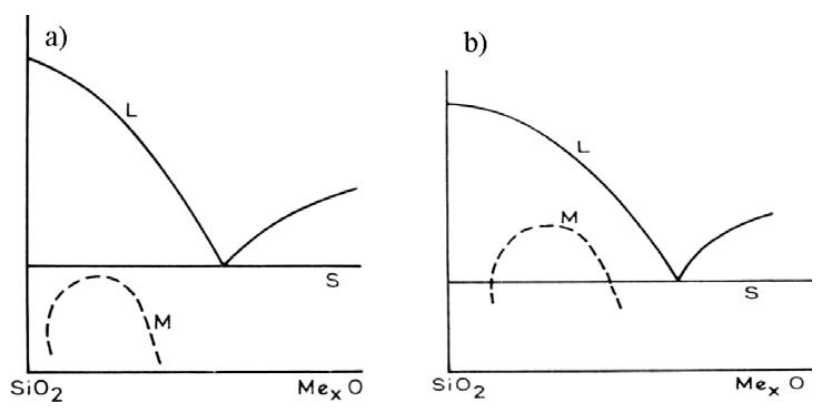

Figure 7: a) Liquid-phase separation below the solidus line in a binary system and b) liquid-phase separation below the liquidus in a binary system $^{9}$

Slika 7: a) Izločanje staljene faze pod solidusno linijo v binarnem sistemu in b) izločanje staljene faze pod likvidusno linijo v binarnem sistemu ${ }^{9}$
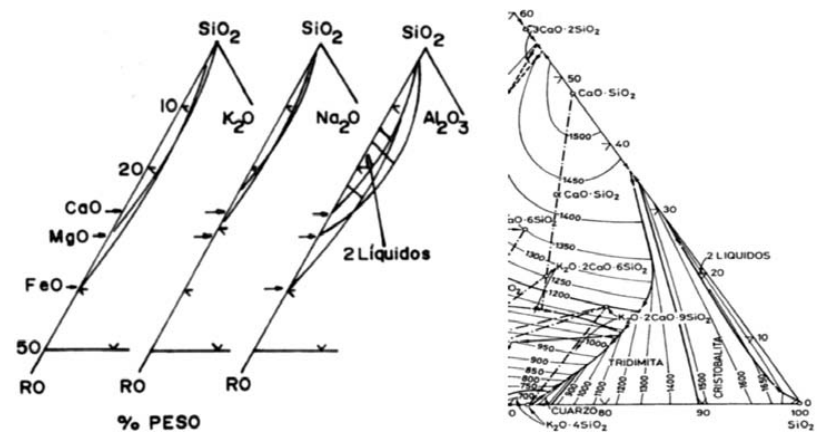

Figure 8: Ternary compositions of glasses showing the narrow glass-in-glass and/or liquid-phase separation zones for the ternary systems: $\mathrm{RO}-\mathrm{K}_{2} \mathrm{O}-\mathrm{SiO}_{2}, \mathrm{RO}-\mathrm{Na}_{2} \mathrm{O}-\mathrm{SiO}_{2}, \mathrm{RO}-\mathrm{Al}_{2} \mathrm{O}_{3}-\mathrm{SiO}_{2}$ and $\mathrm{K}_{2} \mathrm{O}-\mathrm{CaO}-\mathrm{SiO}_{2}{ }^{6}$

Slika 8: Ternarna sestava stekel, ki prikazuje ozko področje steklo v steklu in/ali področje izločanja taline $\mathrm{v}$ ternarnih sistemih: $\mathrm{RO}-\mathrm{K}_{2} \mathrm{O}-$ $\mathrm{SiO}_{2}, \mathrm{RO}-\mathrm{Na}_{2} \mathrm{O}-\mathrm{SiO}_{2}, \mathrm{RO}-\mathrm{Al}_{2} \mathrm{O}_{3}-\mathrm{SiO}_{2}$ in $\mathrm{K}_{2} \mathrm{O}-\mathrm{CaO}-\mathrm{SiO}_{2}{ }^{6}$

small crystals of wollastonite $\left(\mathrm{CaO}-\mathrm{SiO}_{2}\right)$ with no glass-in-glass phase separation. Conversely, the compositions of M-8 and M-9 show a phase separation during the TEM replica observations of the droplets that must be enriched with $\mathrm{SiO}_{2}$ according to the theory of the phase separation in glasses ${ }^{5,6}$. This fact made us think that there is a dome below the liquidus in this zone, consisting of silica + liquid zone and that this is the only explanation for the immiscibility in these glasses, considering the simplification of this composition system.

This proposed cupula or dome of immiscibility is congruent with the inclusion of the third modifier cations in these glasses (Tables $\mathbf{1}$ and 2) and the relative location of immiscibility in the binary systems, as can be seen in Figure 6, where an extension of the immiscibility in this area and/or, as proposed, the second immiscibility dome occurring below the liquidus can be found in this area of the simplified phase diagram. Even more, if we consider the ternary systems of $\mathrm{Na}_{2} \mathrm{O}-\mathrm{CaO}-\mathrm{SiO}_{2}, \mathrm{~K}_{2} \mathrm{O}-\mathrm{CaO}-\mathrm{SiO}_{2}$ and $\mathrm{Al}_{2} \mathrm{O}_{3}-\mathrm{CaO}-\mathrm{SiO}_{2}$ the phase-separation areas are very

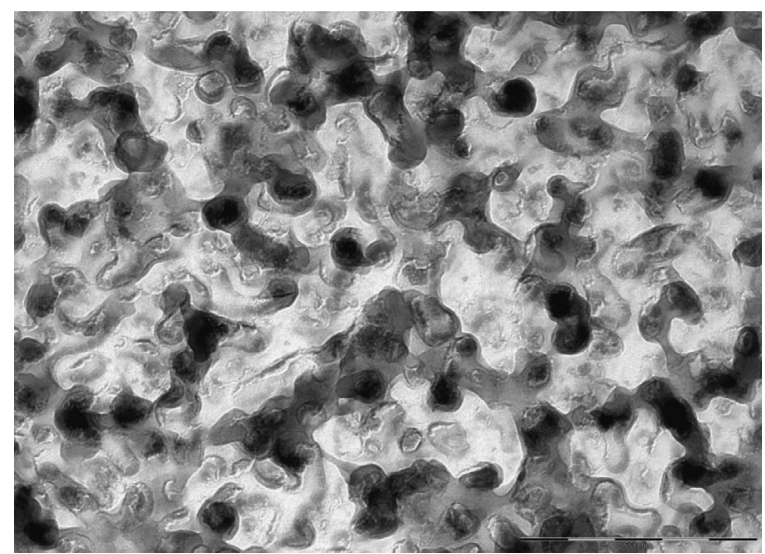

Figure 9: Microstructure of the M-8 miserite glass showing a spinodal-like decomposition

Slika 9: Mikrostruktura mizeritnega stekla M-8, ki kaže razgradnjo, podobno spinodalni reakciji 
narrow being the miserite glasses within the limits of these immiscibility zones.

Therefore, the presence of liquid immiscibility in these glasses is very critical but, in any case, favored by the presence of fluorine ions in a glass network structure. As shown in Figure 6, this area of the metastable immiscibility in miserite glasses can be produced at the $1436{ }^{\circ} \mathrm{C}$ solidus limit and extended below such a solidus line in the metastable conditions, which are the usual liquid-freezing conditions for obtaining glasses. Another possible hypothesis is that the known area of the metastable miscibility at the solidus where the eutectic and the liquidus line of the monotectic reaction $\left(1705^{\circ} \mathrm{C}\right)$ are located can be extended or widened to the lower silica amount in this diagram. This situation is well-known in the binary $\mathrm{R}_{2} \mathrm{O}-\mathrm{SiO}_{2}$ systems as shown in Figure $7^{9}$ and even in the corresponding ternary diagrams (Figure 8) ${ }^{5,6}$.

The miserite M-8 glass shows, in some zones, an interconnected-droplet microstructure, while this type of immiscibility microstructure was not observed in the other miserite glasses (Figure 9). In principle, this may correspond to the spinodal decomposition as demonstrated by the Cahn theory for the compositions in the center of the phase-separation cupolas ${ }^{5,6}$. In this case, while observing the relative location of the M- 8 glass in a simplified pseudobinary system involving $\mathrm{CaO}$ (Figure 6) it can be seen that this composition is close to the centre of the proposed second dome, close to $T_{\mathrm{c}}$, the temperature of the maximum immiscibility for the binary domes. Therefore, in spite of the very narrow areas of the phase separation in the basic composition of the $\mathrm{K}_{2} \mathrm{O}-\mathrm{CaO}-\mathrm{Al}_{2} \mathrm{O}_{3}-\mathrm{SiO}_{2}$ glasses and the similarly that was demonstrated by Chiang and Kingery ${ }^{10}$ it is possible to obtain the glasses with a liquid-liquid immiscibility according to the several microstructures of the phaseseparation phenomena.

Finally, it is evident that this immiscibility can be observed with scanning electron microscopy (SEM). However, our experience in observing this effect in glasses showed that a clear definition of immiscibility is only possible when revisiting the traditional TEM replica method, as was the case in this investigation. More research is now in progress involving different compositions of mica glass-ceramics such as fluorphlogopite and others ${ }^{11}$.

\section{CONCLUSIONS}

The TEM replica method was revisited to study the microstructures of the original fluoride-miserite glasses, using the conventional TEM, and to elucidate the phase separation inherent to these opalescent glasses. These liquid-liquid and/or glass-in-glass phase separations strongly depend on the fluorine level in a vitreous structure, reaching the maximum values with the lowest fluorine amounts. At higher fluorine concentrations there are precipitations of $\mathrm{Ca}_{2} \mathrm{~F}$ and the nanocrystals of wollastonite, cuspidine and/or miserite, depending on the glass composition.

\section{Acknowledgement}

The authors wish to thank for the facilities provided by the Polytechnic University of Valencia (UPV), Servei de Microscopia Electronica, and the valuable help from Manuel Planes when using the TEM equipment. They also thank Eduardo Cabrero, IETcc, CSIC, for helping them draw the original figures and Dr. M. Romero from the IETcc-CSIC for giving valuable advice to R. Casasola regarding her $\mathrm{Ph}$. D. Thesis.

\section{REFERENCES}

${ }^{1}$ A. G. Guy, Essentials of Materials Science, McGraw-Hill, 1976, 97

2 J. Ma. Rincón, Principles of nucleation and controlled crystallization of glasses, Polym. Plast. Technol. Engineering, 31 (1992) 3-4, 309-357, doi:10.1080/03602559208017751

${ }^{3}$ R. Casasola, J. M. Pérez, J. Ma. Rincón, M. Romero, 50th Congress of the Spanish Glass and Ceramics Society VI-P-01, Bol. Soc. Esp. Ceram. Vidr., 49 (2010) 5, 35

${ }^{4}$ J. Ma. Rincón, Microstructural characterization by electron microscopy of ceramics and glasses, Microscopy and Analysis, (1996), 23-25

${ }^{5}$ J. Ma. Rincón, Separación de fases en el vidrio, Bol. Soc. Esp. Ceram. Vidr., 11 (1972) 1, 111-125

${ }^{6}$ J. Ma. Rincón, A. Durán, Separación de fases en Vidrios, El Sistema $\mathrm{Na}_{2} \mathrm{O}-\mathrm{B}_{2} \mathrm{O}_{3}-\mathrm{SiO}_{2}$, Edited by the Spanish Glass and Ceramic Society, SECV, Arganda del Rey, Madrid, 1982

${ }^{7}$ J. Ma. Rincón, P. Callejas, F. Capel, Fractografía de vidrios y materiales vitrocristalinos, Bol. Soc. Esp. Ceram. Vidr., 28 (1989) 4, 257-267

${ }^{8}$ J. R. Taylor, A. T. Dinsdale, Thermodynamic and phase diagram data for the $\mathrm{CaO}-\mathrm{SiO}_{2}$ system, Calphad, 14 (1990) 1, 71-88, doi:10.1016/ 0364-5916(90)90041-W

${ }^{9}$ E. Plumat, La formation de systèmes pseudo-vitreux et pseudo-cristallines, Silicates Industriels, 1 (1967), 5-13

${ }^{10}$ Y. M. Chiang, W. D. Kingery, Spinodal decomposition in a $\mathrm{K}_{2} \mathrm{O}-\mathrm{Al}_{2} \mathrm{O}_{3}-\mathrm{CaO}-\mathrm{SiO}_{2}$ glass, Journal of the Amer. Ceram. Soc., 66 (1983) 9, c171-c172, doi:10.1111/j.1151-2916.1983.tb10632.x

${ }^{11}$ R. Casasola, Ph. D. Thesis, Autonoma University of Madrid, 2013 